\title{
MANFAAT PARIWISATA GOA KREO DAN WADUK JATIBARANG BAGI \\ PEREKONOMIAN DAN LINGKUNGAN MASYARAKAT \\ (Studi Empiris: Desa Kandri, Kecamatan Gunung Pati, Kota Semarang)
}

\author{
Debik Untan
}

Fakultas Ekonomika dan Bisnis Universitas Diponegoro

Email : debikuntann@gmail.com

\author{
Edy Yusuf Agung Gunanto \\ Mulyo Hendarto \\ Darwanto
}

Fakultas Ekonomika dan Bisnis Universitas Diponegoro

\begin{abstract}
Abstrak
Pengembangan pariwisata Waduk Jatibarangdan Goa Kreo telah mengubah kondisi sosial ekonomi masyarakat sekitar, masyarakat yang dahulu bekerja sebagai petani dan buruh tanikini beralih profesi sebagai dampak dari pengembangan lokasi wisata tersebut, masyarakat sekitar kehilangan lahan persawahan mereka karena adanya pembangunan Waduk Jatibarang, Dampaknya berpengaruh terhadappekerjaan dan pendapatan yang diterima masyarakat sekitar. Tujuan dari penelitian ini untuk menganalisa bagaimana tingkat perbedaan pendapatan yang diterima oleh masyarakat sekitar sebelum dan sesudah adanya pengembangan objek pariwisata Goa Kreo dan Waduk Jatibarang, apa yang menyebabkan perbedaan tingkat pendapatan yang diterima masyarakat dan dampaknya terhadap perekonomian, dan bagaimana dampak pengembagan lokasi wisata Goa Kreo dan Waduk Jatibarang tersebut terhadap kondisi non-ekonomi. Metode penelitian ini mengunakan mix method dengan mengunakan deskriptif kuantatif dan diskriptif kualitatif. Hasil dari penelitian ini yaitu, pendapatan yang diterima oleh masyarakat sekitar kawasan wisata Goa Kreo dan Waduk Jatibarang meningkat seiring dengan adanya pengembangan wisata, meningkatnya kesempatan kerja dan nilai ekonomis tanah. Sedangkan pengembangan lokasi wisata Goa Kreo dan Waduk Jatibarang juga akan berpengaruh terhadap kondisi sosial masyarakat, kondisi kebudayaan dan lingkungan masyarakat sekitar pada aspek non-ekonomi.
\end{abstract}

Kata kunci: Ekonomi Pariwisata, Goa Kreo, Waduk Jatibarang, Pariwisata berbasis Masyarakat.

\section{Abstract}

Tourism development Jatibarang reservoirs and Goa cave has changed the socioeconomic conditions surrounding communities, people who formerly worked as farmers and farm workers are now turning the profession as a result of the development of the tourist sites, local communities lost land of their rice fields because of the construction of reservoirs Jatibarang, impact effect on employment and earned income communities. The purpose of this study was to analyze how the different levels of income received by the local community before and after the development of tourism objects Kreo cave and Jatibarang reserviors, what causes the difference in the level of income received by the community and the impact on the economy, and how the impact of developing a tourist location Kreo cave and the Jatibarang reservoir against non-economic conditions. This research method using a mix method by using descriptive quantitative and descriptive qualitative. The results of this study, namely, the income received by people around the tourist area of Goa and dams Jatibarang Kreo increase along with the expansion of the travel, increasing employment opportunity and the economic value of land. Beside that development of tour sites, Jatibarang resevoir and Goa Kreo also affec tpt the social conditions, culture and environment conditions surrounding communities in non-economic aspect.

Keywords: Tourism Economics, Goa Kreo, Jatibarang Reservoir, Community-based Tourism. 


\section{PENDAHULUAN}

Pariwisata adalah industri yang tergolong memiliki perkembangan yang cepat dewasa ini, selain itu pariwisata dianggap sebagai industri yang menarik untuk dikembangkan dan mempunyai posisi yang strategi dalam perkembangan perekonomian khususnya di Indonesia. Peranan pariwisata mengalami peningkatan seiring adanya perkembangan perdagangan dan investasi pada era globalisasi. Kekayaan alam dan ragam budaya menjadi nilai tambah bagi upaya pengembangan pariwisata di Indonesia. Pengembangan pariwisata dapat memacu pertumbuhan perekonomian sekaligus melestarikan alam dan budaya Indonesia. Selain itu pula pengembangan pariwisata berdampak positif terhadap eratnya persaudaraan dan persahabatan nasional maupun internasional (Yoeti, 1982).

Kota Semarang yang menjadi ibu kota Provinsi Jawa Tengah memiliki sumber daya yang dapat diolah sebagai produk wisata yang menarik bagi wisatawan domestik maupun wisatawan internasional. Posisi Kota Semarang dapat dikatakan cukup strategis karena berada pada jalur perlintasan utama di Pulau Jawa. Kondisi ini tentunya menguntungkan bagi Pemerintah Kota Semarang dalam upaya mempromosikan objek wisata yang terdapat di Kota Semarang.Kota Semarang memiliki berbagai objek pariwisata seperti wisata alam, wisata sejarah, wisata religi, wisata keluarga, hingga wisata belanja dan kuliner.

Tabel1.Jumlah Kunjungan Wisata Mancanegara dan Wisatawan Lokal Kota Semarang Tahun 2009 - 2013

\begin{tabular}{ccc}
\hline No & Tahun & Jumlah (orang) \\
\hline \hline 1 & 2009 & 1.633 .042 \\
2 & 2010 & 1.915 .892 \\
3 & 2011 & 2.100 .926 \\
4 & 2012 & 2.712 .442 \\
5 & 2013 & 3.157 .658 \\
\hline \hline
\end{tabular}

Sumber: Dinas Kebudayaan dan Pariwisata Kota Semarang Tahun 2013
Kota Semarang memiliki beberapa destinasi wisata alam, diantaranya Pulau Tirangcawang di Kelurahan Tugu, Pantai Tirang di Kelurahan Tambak Harjo, Pantai Marina di Kelurahan Tawangsari, Pantai Maron di Kelurahan Tambak Harjo, Goa Kreo dan Waduk Jatibarang di Kelurahan Kandri, Taman Lele Semarang di Kelurahan Tambakaji. Salah satu obyek wisata yang saat ini menjadi tempat wisata yang banyak digemari oleh masyarakat khususnya masyarakat Kota Semarang dan Jawa Tengah adalah wisata Goa Kreo dan Waduk Jati Barang yang baru diresmikan pada tahun 2014. Terletak di Dukuh Talun Kacang, Kelurahan Kandri, Kecamatan Gunungpati, Kota Semarang. Obyek wisata Goa Kreo dan Waduk Jatibarang ini merupakan suatu produk pariwisata yang banyak diminati oleh wisatawan di Kota Semarang. Goa Kreo adalah sebuah Goa yang merupakan petilasan Sunan Kalijagak etika bertemu dengan sekawanan kera yang kemudian disuruh menjaga kayu jati tersebut. Kata "Kreo" sendiri berasal dari kata Mangreho yang berarti peliharalah atau jagalah, yang kemudian menjadikan goa ini disebut Goa Kreo dan sejak itu kawanan kera yang menghuni kawasan Gua Kreo dianggap sebagai penunggu.

Hal ini dapat dilihat dari jumlah kunjungan wisatawan yang cukup banyak, sejak diresmikannya Waduk Jatibarang pada tahun 2014, jika dilihat dari Gambar 1 peningkatan cukup signifikan terjadi pada tahun 2014. Berbeda jauh jika dibandingkan dengan tahun 2012.

Jumlah kunjungan wisatawan di Goa Kreo yang cukup besar tentunya akan memberikan dampak secara langsung kepada masyarakat sekitar Goa Kreo dan Waduk Jatibarang. Pembangunan Waduk Jatibarang seluas 46,56 hektar memiliki banyak manfaat dalam pengembangan pariwisata di kawasan tersebut. Namun di sisi lain pembangunan Waduk Jatibarang tersebut mengorbankan lahan persawahan warga masyarakat Desa Kandri dalam pembangunannya. Sebagai kompensasi, masyarakat yang lahan persawahannya 
terkena dampak pembangunan waduk diberikan ganti rugi atas tanah yang dimiliki dan diberikan kesempatan untuk berdagang atau bekerja di kawasan wisata Goa Kreo maupun Waduk Jatibarang.

Banyaknya kunjungan wisata ke Goa Kreo dan Waduk Jatibarang tentunya akan membuka kesempatan bagi masyarakat sekitar untuk melakukan kegiatan usaha dengan menyediakan berbagai macam kebutuhan wisatawan selama berkunjung ke lokasi wisata Goa Kreo dan Waduk Jatibarang. Peluang ini masyarakat sekitar dapat memanfaatkan dengan cara menawarkan berbagai barang-barang yang dibutuhkan oleh wisatawan, menjual jasa, ataupun berjualan makanan. Bertambahnya jumlah kunjungan wisatawan secara otomatis akan menambah kebutuhan wisatawan akan barang dan jasa yang ditawarkan, sehingga akan berdampak pada adanya peluang bagi masyarakat untuk mendapatan tambahan pendapatan.

Terlebih lagi pemerintah melalui Dinas Pariwisata dan Kebudayaan Kota Semarang mentargetkan jumlah kunjungan wisata mengalami peningkatan sepanjang tahun, hal ini disampaikan oleh Kepala $\mathrm{Ka}$ UPTD Goa Kreo bapak Asron. Langkah pemerintah tersebut terbukti dari pembangunan infrastruktur seperti jalan raya menuju Goa Kreo yang sedang diperbaiki dan penambahan fasilitasfasilitas bagi wisatawan yang ada di Goa Kreo.Pernyataan Ditjenpar dalam Pendit (1991) menjelaskan bahwa pembangunan desa wisata diharuskan untuk mempertimbangkan kemampuan dan tingkat penerimaan lokasi pengembangan desa wisata. Tentunya pengembangan wisata yang ada di kawasan Goa Kreo dan Waduk Jatibarang harus mempunyai dampak bagi yang positif terhadap perekonomian masyarakat sekitar, pembukaan lapangan pekerjaan, pemerantaan pendapatan, serta peningkatan pendapatan daerah.

Berdasarkan uraian tersebut, permasalahan penelitian yang diajukan adalah: bagaimanakah perbedaan pendapatan yang diterima oleh masyarakat sekitar sebelum dan sesudah adanya pengembangan objek pariwisata Goa Kreo dan Waduk Jatibarang? Apakah penyebab perbedaan tingkat pendapatan yang diterima masyarakat dan dampaknya terhadap perekonomian? Serta bagaimanakah dampak pengembangan lokasi wisata Goa Kreo dan Waduk Jatibarang tersebut terhadap kondisi non-ekonomi.



Sumber: Dinas Kebudayaan dan Pariwisata Kota Semarang

Gambar 1. Jumlah Kunjungan Wisatawan Tahun 2009 - 2014 


\section{TINJAUAN PUSTAKA}

\section{Pengertian Pariwisata}

J. Burkart dan S. Malik (Soekadijo, 2000) mengartikan pariwisata sebagai berpindahnya individu ke suatu tempat yang berlokasi di luar tempat biasaya individu tersebut melakukan aktivitas sehar-hari dalam sementara ataupun jangka waktu pendek. Sedangkan menurut Salah Wahab (Yoeti, 1995) menjelaskan pariwisata sebagai suatu aktivitas individu yang disertai dengan kesadaran dan individu tersebut memperoleh pelayanan dari masyarakat lokal di suatu lokasi untuk sementara waktu dengan tujuan mencapai kepuasan yang beragam dan berbeda dari lingkungan asal individu tersebut.

Faktor-faktor penting yang dalam pengertian pariwisata yang perlu diperhatikan disebutkan Yoeti (1995) antara lain: 1) perjalanan dilakukan sementara waktu; 2) perjalanan dilakukan dari suatu lokasi menuju ke lokasi lain; 3) perjalanan memiliki keterkaitan dengan tamasya atau rekreasi; 4) individu yang melakukan perjalanan berlaku sebagai konsumen di lokasi wisata bukan sebagai seseorang yang mencari penghasilan. Sumber daya yang berada di suatu daerah dapat dikembangkan menjadi suatu bentuk atraksi wisata dengan mempertimbangkan aspek lainnya yang dapat bermanfaat bagi kepentingan ekonomi disebut sebagai suatu potensi wisata (Pendit, 2002). Atraksi wisata atau daya tarik wisata dijelaskan oleh Yoeti (2002) sebagai segala sesuatu yang dapat menarik wisatawan untuk berkunjung pada suatu daerah tujuan wisata, seperti: atraksi alam (landscape, pemandangan laut, pantai, iklim dan fitur geografis lain dari tujuan), daya tarik budaya (sejarah dan cerita rakyat, agama, seni dan acara khusus, festival), atraksi sosial (cara hidup, populasi penduduk, bahasa, peluang untuk pertemuan sosial), dan daya tarik bangunan (bangunan, arsitektur bersejarah dan modern, monumen, taman, kebun, marina).

\section{Community Based Tourism (CBT)}

Community Based Tourism (CBT)

merupakan konsep pengembangan suatu destinasi wisata melalui pemberdayaan masyarakat lokal dengan melibatkan masyarakat dalam perencanaan, pengelolaan, dan pengambilan keputusan dalam pembangunannya (Murphy, 2005). Pengembangan pariwisata dengan melibatkan peranan komunitas perlu mempertimbangkan aspek-aspek non ekonomi seperti keberlanjutan lingkungan, sosial dan budaya dan pengembangan pariwisata tidak cenderung pada aspek-aspek ekonomi yang merupakan dampak dari adanya aspek sosial, budaya dan lingkungan (Anstrand, 2006). Sedangkan menurut Suansri (2003) menambahkan bahwa CBT merupakan suatu bentuk alat yang dipergunakan untuk tujuan pembangunan komunitas dan konservasi lingkungan.

Patin dan Francis (2005) mendefinisikan CBT sebagai integrasi dan kolaborasi antara pendekatan dan alat (tool) untuk pemberdayaan ekonomi komunitas, melalui assessment, pengembangan dan pemasaran sumber daya alam dan sumber daya budaya komunitas. Hausler (2005), menjelaskan gagasan tentang definisi dari CBT yaitu: pertama, bentuk pariwisata yang memberikan kesempatan kepada masyarakat lokal untuk mengontrol dan terlibat dalam manajemen dan pembangunan pariwisata; kedua, masyarakat yang tidak terlibat langsung dalam usaha-usaha pariwisata juga mendapat keuntungan ; ketiga, menuntut pemberdayaan secara politis dan demokratisasi dan distribusi keuntungan kepada komunitas yang kurang beruntung di pedesaan. Dengan demikian dalam pandangan Hausler, Community Based Tourism (CBT) merupakan suatu pendekatan pembangunan pariwisata yang menekankan pada masyarakat lokal (baik yang terlibat langsung dalam industri pariwisata maupun tidak) dalam bentuk memberikan kesempatan (akses) dalam manajemen dan pembangunan pariwisata 
yang berujung pada pemberdayaan politis melalui kehidupan yang lebih demokratis, termasuk dalam pembagian keuntungan dari kegiatan pariwisata yang lebih adil bagi masyarakat lokal. Hausler juga menyampaikan gagasan tersebut sebagai wujud perhatian yang kritis pada pembangunan pariwisata yang seringkali mengabaikan hak masyarakat lokal di daerah tujuan wisata.

Pengembangan pariwisata dengan melibatkan komunitas masyarakat lokal dianggap memiliki peluang untuk pengembangan objek-objek dan atraksi wisata berskala kecil yang berdampak pada minimalnya sosial-kultural sehingga terdapat peluang yang lebih besar untuk diterima oleh masyarakat lokal (Nasikun, 2001). Hatton (1999) menggambarkan prinsip-prinsip dasar dari Community Based Tourism (CBT) antara lain : 1) prinsip sosial yaitu berkaitan otorisasi kepada komunitas untuk memberi ijin, mendukung, membangun dan mengoperasikan kegiatan wisata di wilayah lokal; 2) prinsip ekonomi yang menjelaskan mengenai pembagian keuntungan dari usaha pariwisata untuk komunitas dan usaha kecil/menengah yang merekrut tenaga kerja dari komunitas; 3) prinsip budaya mensyaratkan adanya upaya menghargai budaya lokal, heritage dan tradisi dalam kegiatan pariwisata; dan 4) prinsip politik berkaitan dengan peran pemerintah lokal dan regional diantaranya dalam membuat kebijakan sehingga prinsip sosial ekonomi, budaya dan dapat terlaksana.

\section{Konsep Pendapatan}

Sukirno (2000) menyatakan bahwa pendapatan merupakan sejumlah penghasilan yang diperoleh dari hasil pekerjaan yang dihitung setiap tahun atau setiap bulan pada umumnya. Pada ekonomi makro, kesejahteraan masyarakat seringkali dikaitkan dengan tingkat pendapatan masyarakat, sehingga banyak kebijakan makro yang bertujuan untuk menaikkan tingkat pendapatan masyarakat. Penda- patan sering kali dikaitkan dengan penawaran tenaga kerja pada ekonomi makro. Pendapatan yang sering diperkecil dengan upah (wage) merupakan salah satu faktor pendorong penawaran tenaga kerja, penghasilan merupakan salah satu alasan utama seseorang untuk bekerja. Keuntungan yang diperoleh akan berpengaruh terhadap semangat dan produktivitas pekerja.

Menurut Sukirno (2002) besaran pendapatan dari tenaga kerja dipengaruhi oleh beberapa faktor, yaitu : faktor demografi, sosio budaya, dan sosio ekonomi. Faktor demografi yang mempengaruhi pendapatan tenaga kerja adalah pengalaman bekerja dan jumlah anggota keluarga yang bekerja. Teknologi yang merupakan salah satu unsur dari faktor sosio ekonomi juga turut berperan dalam mempengaruhi pendapatan tenaga kerja. Pendapatan dalam pengertian ekonomi merupakan balas jasa atas penggunaan faktor-faktor produksi yang dimiliki oleh sektor rumah tangga dan sektor perusahaan yang berupa gaji/upah, sewa, bunga serta keuntungan/profit.

\section{METODE PENELITIAN}

Metode pengambilan sampel yang digunakan dalam penelitian ini adalah nonprobability sampling dengan bentuk quota accidental sampling. Sampel dalam penelitian ini adalah Masyarakat sekitar Objek Wisata Goa Kreo dan Waduk Jatibarang yang berjumlah 50 Orang, serta beberapa key person yakni para masyarakat di Goa Kreo, Waduk Jatibarang dan di luar objek wisata, kepala pengelola kawasan wisata Goa Kreo dan sekretaris pengelola kawasan wisata Waduk Jatibarang untuk memperoleh informasi terkait pemecahan masalah penelitian. Jenis data yang digunakan dalam pelitian ini adalah data primer yang diperoleh dari hasil wawancara dan data sekunder yang bersumber dari buku, website, Badan Pusat Statistik (BPS), laporan resmi dari pemerintah serta literatur berupa jurnal dan sebagainya. 


\section{Metode Analisis}

Metode penelitian yang digunakan dalam penelitian ini adalah mix method (metode gabungan) yakni dengan menggunakan metode penelitian deskriptif kuantitatif dan deskriptif kualitatif. Metode penelitian kuantitatif yang digunakan dalam penelitian ini adalah dengan alat analisis deskriptif (frekuensi). Sedangkan, untuk metode deskriptif kualitatif digunakan adalah teknik analisis mendalam (in-depth analysis).

\section{Wawancara Mendalam (In-depth analysis)}

Merupakan teknik analisis dengan cara wawancra mendalam, untuk mengkaji masalah secara kasus per kasus karena metodologi kualitatif yakin bahwa sifat suatu masalah satu akan berbeda dengan sifat dari masalah lainnya. Prosedur dalam menganalisis penelitian ini yakni pertama melakukan pra survey untuk mengidentifikasi permasalahan yang ada, kemudian peneliti mencoba merumuskan permasalahan yang ada, menyusun pertanyaan dan melakukan in-depth interview kepada para responden, terdiri dari masyarakat sekitar Objek Wisata Goa Kreo dan Waduk Jatibarang yang berjumlah, serta beberapa key person yakni para masyarakat di Goa Kreo, Waduk Jatibarang dan di luar objek wisata, kepala pengelola kawasan wisata Goa Kreo dan sekretaris pengelola kawasan wisata Waduk Jatibarang sebagai key informan guna memperoleh informasi dan melakukan kajian literatur serta menarik kesimpulan berdasarkan keadaan sebenarnya di lapangan.

\section{HASIL DAN PEMBAHASAN \\ Karateristik Responden}

Karateristik responden berdasarkan jenis usaha

Dari keseluruhan jumlah pelaku usaha yang berada di kawasan wisata Goa Kreo dan Waduk Jatibarang peneliti mengambil 50 responden sebagai objek dalam penelitian ini dengan rincian seperti yang ditampilkan dalam Tabel 2 .

Tabel 2 menjelaskan 23 Orang responden atau sebesar $46 \%$ bekerja sebagai pedagang di kawasan Goa Kreo, 12 Orang responden atau sebesar 24\% bekerja sebagai pemilik speedboat, 11 Orang responden atau sebesar $22 \%$ bekerja di luar objek dan 4 Orang responden atau sebesar $8 \%$ bekerja sebagai pedagang di kawasan Waduk Jatibarang. Masyarakat berganti pekerjaan dengan berbagai alasan, selain karena dampak pembangunan Waduk Jatibarang, banyak juga masyarakat yang berganti pekerjaandengaan berjualan di kawasan wisata karena dirasa lebih menguntungkan dibandingkan dengan menjadi buruh.

\section{Karakteristik responden berdasarkan pendapatan}

Hal ini digunakan untuk melihat bagaimana proporsi responden dilihat dari jumlah pendapatan yang diterima tiap bulan, pendapatan dalam penelitian ini merupakan pendapatan bersih yang diterima oleh responden selama satu bulan penuh dia bekerja, dalam penelitian ini juga memperhatikan bagaimana potensi perbedaan pendapatan yang mungkin diterima oleh pada hari biasa dan hari besar (Sabtu, Minggu dan hari libur nasional) untuk mendapatkan data yang sesuai dan akurat.

Tabel 3 menjelaskan bahwa sebanyak tiga responden atau sebesar $6 \%$ dari total keseluruhan responden mendapatkan pendapatan $\leq 1000.000$ Rupiah per bulan, sebanyak 22 responden atau sebesar 44\% dari total keseluruhan responden mendapatkan pendapatan sebesar 1000.001-2000.000 Rupiah per bulan, sebanyak 13 responden atau $26 \%$ dari total responden mendapatkan pendapatan sebesar 2000.001-3000.000 Rupiah dalam 1 bulan, sebanyak 8 responden atau $16 \%$ dari total keseluruhan responden mendapatkan penghasilan sebesar 3000.001-4000.000 Rupiah dalam 1 bulan, sebanyak 2 orang responden atau $4 \%$ dari 
total keseluruhan responden mendapatkan pendapatan sebesar 4000.001-5000.000 Rupiah dalam 1 bulan, dan sebanyak 2 orang atau sebesar 2\% dari total keseluruhan responden mendapatkan penghasilan sebesar $\geq 5.000 .000$ Rupiah dalam 1 bulan. Tidak semua responden dalam penelitian ini melakukan pekerjaannya setiap hari, ada banyak responden yang hanya bekerja pada hari hari besar saja.

\section{Peralihan Profesi Masyarakat}

Hasil observasi yang dilakukan dalam penelitian, terdapat 99 masyarakat yang berprofesi sebagai pelaku usaha ataupun sebagai penyedia layanan kepariwisataan. Berdasarkan keseluruhan jumlah pelaku usaha tersebut, diambil 50 responden sebagai objek dalam penelitian ini. Latar belakang pekerjaan pelaku usaha sebelum alih profesi yang disajikan pada Gambar 3.

Responden yang berjumlah 23 orang yang bekerja di kawasan Goa Kreo terdapat sebanyak 10 orang atau sebesar $44 \%$ berlatar belakang sebagai petani, 6 orang atau sebesar $26 \%$ berlatar belakang sebagai buruh pabrik. 2 orang atau sebesar $9 \%$ berlatar belakang sebagai bangunan, 4 orang atau sebesar $17 \%$ berlatar belakang sebagai buruh petani, 1 orang atau sebesar $4 \%$ berlatar belakang sebagai buruh lepas. Sebaliknya 20 orang masyarakat yang dahulunya bekerja sebagai petani kemudian diperinci lagi berdasarkan profesi yang ditekuni saat ini, perincian ini di tampilkan dalam diagran lingkar yang ditunjukkan oleh Gambar 4. Sebanyak 12 orang atau sebesar $60 \%$ berprofesi sebagai pedagang di Goa Kreo, 3 orang atau sebesar $15 \%$ berprofesi sebagai pemilik persewaan speedboat, 2 orang atau sebesar $10 \%$ berprofesi sebagai pedagang di kawasan Waduk Jatibarang, 2 orang atau sebesar $10 \%$ berprofesi sebagai pemilik warung makan di luar objek, dan 1 Orang atau sebesar $5 \%$ berprofesi sebagai pemilik toko klontong.

Tabel 2. Jumlah Responden berdasarkan Jenis Pekerjaan (\%)

\begin{tabular}{ccc}
\hline Jenis pekerjaan & Jumlah responden (orang) & Persentase (\%) \\
\hline \hline Pedagang Goa Kreo & 23 & 46 \\
Pedagang Jatibarang & 4 & 8 \\
Sewa speedboat & 12 & 24 \\
Pedagang di luar & 11 & 22 \\
objek & 50 & 100 \\
Jumlah &
\end{tabular}

Sumber: data primer, diolah 2016

Tabel 3. Karakteristik Responden berdasarkan Pendapatan

\begin{tabular}{ccc}
\hline Pendapatan (Rupiah) & Jumlah Responden (orang) & Persentase (\%) \\
\hline \hline$\leq 1000.000$ & 3 & 6 \\
$1000.001-2000.000$ & 22 & 44 \\
$2000.001-3000.000$ & 13 & 26 \\
$3000.001-4000.000$ & 8 & 16 \\
$4000.001-5000.000$ & 2 & 4 \\
$\geq 5000000$ & 2 & 4 \\
Jumlah & 50 & 100 \\
\hline \hline
\end{tabular}

Sumber: Data Primer, diolah 2016. 


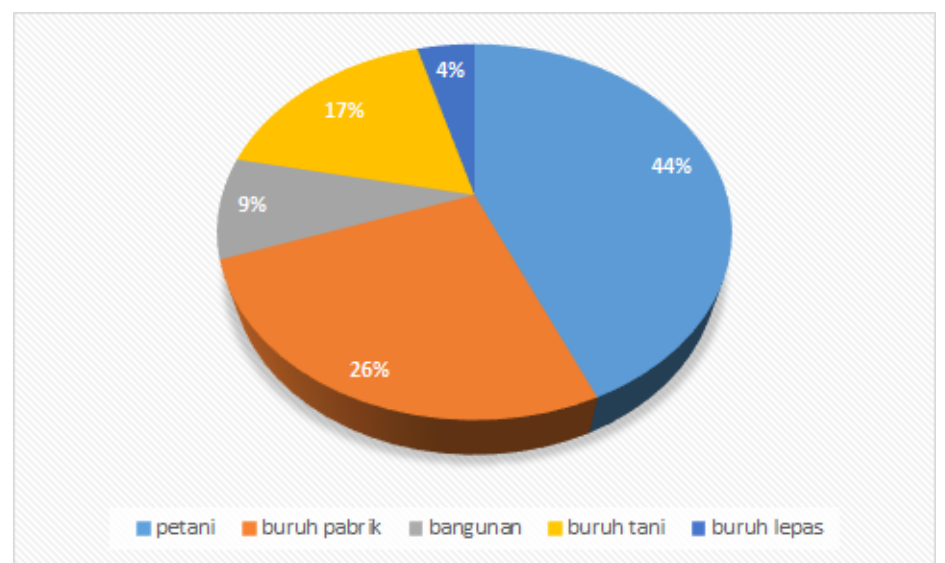

Sumber: Data Primer, diolah 2016.

Gambar 3. Latar Belakang Pekerjaan Pelaku Usaha di Goa Kreo

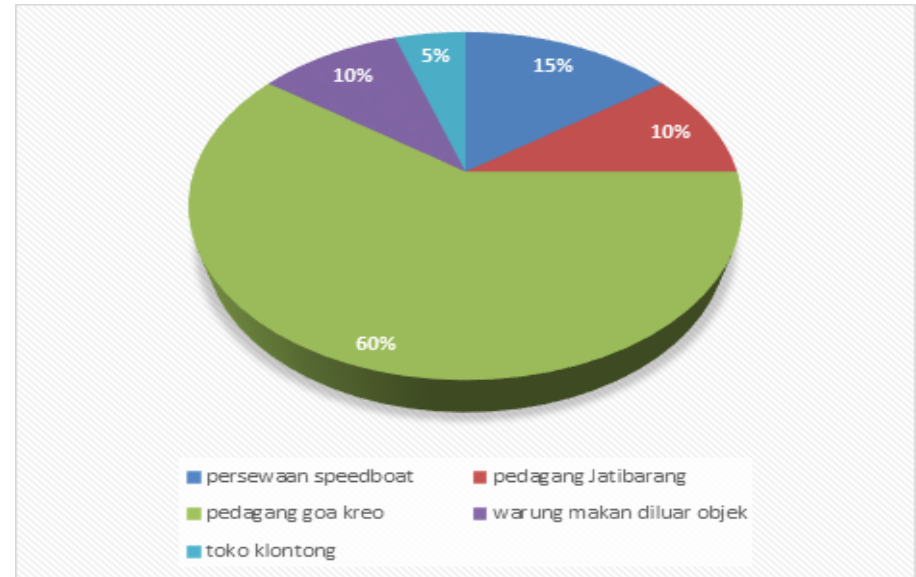

Sumber: data primer, diolah 2016

Gambar 4. Profesi Masyarakat Lokal

\section{Dampak Pariwisata Terhadap Kondisi Ekonomi Dampak pada Pendapatan Masyarakat}

Tabel 4. Rata-rata Pendapatan Responden

\begin{tabular}{llll}
\hline & & Mean & $\mathrm{N}$ \\
\hline \hline \multirow{2}{*}{ Pair 1 } & sebelum & 1223200 & 50 \\
& sesudah & 2543200 & 50 \\
\hline \hline
\end{tabular}

Sumber: data primer, diolah 2016

Tabel 2 menjelaskan bahwa ada perubahan rata-rata pendapatan yang diterima oleh masyarakat yang cukup signifikan, jika dibandingkan dengan pendapatan yang diterima sebelumnya. Dari 50 sampel responden yang diambil, pendapatan yang diterima oeleh masyarakat sebelum adanya penegmbangan objek wisata memiliki nilai rata - rata sebesar Rp. 1.223.200. Setelah adanya pengembangan objek wisata nilai rata - rata pendapatan yang diterima masyarakat naik menjadi sebesar sebesar Rp. 2.543.200.

\section{Dampak pada Pekerjaan Masyarakat}

Pengembangan lokasi pariwisata Goa Kreo dan Waduk Jatibarang secara tidak langsung telah mengubah struktur perekonomian masyarakat di sekitar daerah tersebut, terutama dalam sektor mata pencaharian masyarakat. Adanya lokasi Goa Kreo dan Waduk Jatibarang memunculkan adanya peluang untuk 
terciptanya lapangan pekerjaan baru yang lebih beragam, saat ini masyarakat di Goa Kreo dan Waduk Jatibarang, yang dahulunya mayoritas penduduk bekerja sebagai petani dan buruh sekarang memiliki alternatif pilihan mata pencaharian lain untuk mendapatkan penghasilan. Alternatif pekerjaan tersebut yaitu profesi yang bergerak di bidang pariwisata, semakin banyak kunjungan wisatawan ke Goa Kreo dan Waduk Jatibarang akan berdampak pada semakin meningkatnya tingkat kebutuhan wisatawan baik itu kebutuhan makanan, hiburan, guide, ataupun yang lainnya. Masyarakat di Goa Kreo dan Waduk Jatibarang mendapatkan manfaat dari adanya lokasi objek pariwisata tersebut. Saat ini masyarakat di kawasan wisata Goa Kreo dan Waduk Jatibarang telah memiliki beragam alternatif profesi seperti menjadi pedagang makanan dan minuman ringan, pemilik warung makan, pemilik toko klontong, penyedia jasa persewaan kapal speedboat, penyedia lahan parkir kendaraan pengunjung di Goa Kreo, sampai persewaan kereta mainan yang disewakan untuk anak-anak di kawasan wisata Goa Kreo.

Berkembangnya lokasi wisata Goa Kreo dan Waduk Jatibarang, setelah Waduk Jatibarang diresmikan pada tahun 2014, dapat dilihat dari mulai banyaknya wisatawan yang berkunjung. Hal ini akan memunculkan peluang usaha baru bagi masyarakat, yaitu untuk memenuhi kebutuhan para wisatawan. Kebutuhan tersebut sangatlah beragam dari kebutuhan makanan, tempat tinggal, oleh-oleh ataupun yang lainya. Pendapat ini sama dengan penelitian sebelumnya yang dilakukan oleh I Wayan (2015) yang menyatakan bahwa pengembangan pariwisata di suatu daerah akan berdampak pada perubahan struktur ekonomi masyarakat khususnya mata pencaharian masyarakat yang ditimbulkan dari adanya peluang usaha sektor tersebut dan ikutannya, Dritasto (2013) menyatakan bahwa dampak ekonomi yang ditimbulkan dari kegiatan wisata pada dasarnya dilihat dari keseluruhan pengeluaran wisatawan untuk akomodasi, konsumsi (baik konsumsi dari rumah maupun di lokasi wisata), biaya perjalanan ke lokasi wisata, pembelian souvenir, serta pengeluaran lainnya. Paul (2012) yang menyebutkan bahwa "The tourism industry is highly labor intensive service industry and hence, it is a valuable source of employment. It provides employment several times more than normal manufacturing industries. Several types of business firms such as hotels, motels, restaurants, transport agencies, travel agents, tour operators, gift shops, car and rickshaw drivers, guide etc. flourish from tourist"

Industri pariwisata merupakan industri yang padat karya, hal ini dapat membuka kesempatan seluas-luasnya bagi masyarakat sekitar untuk mengembangkan dan memperoleh keuntungan secara ekonomi. Buktinya saat ini sudah banyak masyarakat sekitar Goa Kreo dan Waduk Jatibarang yang berprofesi sebagai pedagang, menurut penuturan Pak Ismanto berikut;

"Kalau sekarang ini mayoritas pedagang, driver speedboat sama ada sebagian yang buruh di pabrik mas, kalau bapak dulunya buruh di pabrik tetapi sambil menjadi tukang bangunan, klo sekarang jaga warung, kadang driver speedboat, kalau ada kerjaan sebagai tukang kadang kadang juga masih mau mas, klo ibuku dah tiap hari dagang di sini”

Banyaknya masyarakat yang beralih profesi menjadi pedagang tidak terlepas dari adanya alih fungsi lahan pertanian masyarakat, lahan persawahan masyarakat yang dulunya digunakan untuk bertani saat ini sudah menjadi Waduk Jatibarang, dengan demikian masyarakat yang dahulu berprofesi sebagai petani ataupun buruh tani harus mencari profesi lain. Pada awalnya Pemerintah Kota Semarang mengalihkan profesi masyarakat yang dulunya petani untuk berbudidaya ikan dengan karamba di waduk, namun karena 
Waduk Jatibarang ini difungsikan sebagai supply air bersih di Kota Semarang, penahan banjir dan PLTA, maka budidaya ikan dengan karamba itu tidak diperbolehkan lagi.

Tidak diperbolehkanya masyarakat untuk budidaya ikan di karamba mengundang polemik baru di masyarakat, kemudian dikumpulkan kembali masyarakat, perangkat desa beserta dengan Pemerintah Kota Semarang untuk mencari solusinya, dalam musyawarah itu ditemukan solusinya agar masyarakat yang dulu berbudidaya ikan beralih ke persewaan speedboat, berikut pernyataan dari pak Ismanto :

"Memang semua petani yang lahannya terkena dampak pembangunan waduk diberikan ganti rugi mas, kalau ganti ruginya pada saat itu di bawah harga pasar dengan kompensasi warga masyarakat dialihkan untuk mencari pendapatan dengan cara lain. Nah dulu itu ada kumpulan mulai dari warga masyarakat, RT dan RW, pemerintah desa dan pemerintah Kota Semarang untuk merumuskan usaha apa yang cocok untuk dijalankan oleh para pemilik lahan jika lahannya digunakan sebagai waduk, nah saat itu warga difasilitasi dan dibolehkan untuk membuat keramba ikan dab berternak ikan, tapi ternyata ternak ikan itu dianggap mencemarkan air, karena air di Waduk Jatibarang ini digunakan untuk supply air bersih ke Kota dan waduk ini digunakan untuk PLTA (Pembangkit listrik tenaga air) maka keramba ikan tidak dibolehkan lagi, kemudian diganti dengan speedboat ini. Yaitu yang dulunya bekerja sebagai petani berganti ke speedboat, ada juga sebagian yang menjadi pedagang yang buruh juga ada"

Sebelum adanya waduk jati barang, pedagang di Goa Kreo juga sudah ada. Namun jumlahnya tidak sebanyak sekarang, menurut penuturan salah satu pedagang di Goa Kreo sebagai berikut:
"Kalau yang dagang di sini itu udah ada dari dulu tapi jumlahnya tidak banyak seperti sekarang, kalau dulu jualanya ya disepanjang jalan itu mas berjejer klo sekarang kan ditata di sini"

Berdasarkan observasi secara langsung penulis di lapangan, Selain berdagang dan persewaan speedboat ada banyak lagi lapangan pekerjaan yang tersedia sebagai dampak adanya pariwisata Goa Kreo dan Waduk Jatibarang, Seperti penyediaan lahan parkir untuk wisatawan, pada hari libur nasional biasanya lokasi wisata ini dibanjiri pengunjung sehingga lahan parkir yang disediakan pengelola tidak mencukupi. Selain itu ada juga warga masyarakat yang menyewakan kereta anak - anak, kereta kecil itu hanya dioperasikan pada hari libur saja dan dikenakan tarif 5.000 rupiah untuk satu anak. Peluang lain yang timbul adalah industri kerajian seperti souvenir, di banyak tempat di kawasan wisata souvenir biasanya dibuat sebagai oleh - oleh khas daerah pariwisata tersebut. Pendapat ini sama dengan Preechaya (2015) yang menyebutkan bahwa The private sectors should be encouraged and supported to participate in developing the tourist attractions in other matters, for example management in lodgings, restaurants, tourism activities and souvenirs, and many others. Dan penelitian Suriya (2009) yang menyebutkan bahwa "Souvenir shop were among top gainers of the tourism benefit. They could expand more than the rate of tourism price increase"

\section{Dampak terhadap Nilai Jual Tanah}

Adanya lokasi wisata yang ramai dikunjungi oleh wisatawan ternyata berdampak pada naiknya harga tanah yang sangat singnifikan dimana, karena tanah dimana dipandang potensial untuk mendirikan usaha, seperti warung makan, restoran, penginapan dan yang lainya. Menurut penuturan beberapa narasumber, bahwa memang ada kenaikan harga tanah 
di kawasan tersebut. Menurut penuturan Pak Ismanto sebagai berikut;

"Klo tanah di sini sekarang sudah mahal mas, tanah ini aja klo di tawar sejuta paling cuma ditertawain mas, klo yang tanah bapak di atas itu di dekat kawasan Goa Kreo kalau jaman dulu cuma 60 juta sekarang mungkin 1 milyar aja gak dikasih mas, kalau tanah itu jaman 2008 itu harganya sekitar 65.000 per $\mathrm{m}^{2}$ sekarang sudah sekitar 2 jutaan mas tanah disini"

Adanya kenaikan harga tanah ini dapat dipandang sebagai hal yang positif, itu berarti tanah dimana semakin memiliki nilai ekonomis dari adanya lokasi wisata tersebut, namun ada efek negatif yang dapat timbul karena harga tanah yang terlalu mahal, Masyarakat yang tidak memiliki modal akan semakin kesulitan untuk mendirikan bangunan dimana, hasilnya masyarakat yang tidak memiliki modal akan sulit untuk mendirikan usaha karena modal awal yang dikeluarkan terlalu besar.

Namun disisi lain kenaikan harga tanah ini memiliki berdampak buruk terhadap pemerataan perekonomian, masyarakat yang memiliki modal yang lebih besar cenderung akan mendapatkan manfaat yang lebih besar dari adanya sektor wisata tersebut. Namun masyarakat yang hanya memiliki modal yang sedikit atau tidak memiliki modal sama sekali akan kehilangan kesempatan untuk mendapatkan manfaat dari adanya pariwisata tersebut. Hal ini berdampak nyata terhadap kenaikan pendapatan yang diterima oleh masyarakat sekitar, dimana masyarakat yang memiliki modal dapat memiliki satu atau lebih usaha sekaligus. Sementara masyarakat yang tidak memiliki modal dan ingin mendirikan usaha akan terhalang dengan mahalnya harga tanah yang ada sehingga sangat sulit bagi masyarakat yang memiliki modal yang sedikit untuk medirikan usaha, ini artinya masyarakat yang bermodal rendah akan semakin sedikit mendapatkan manfaat dari adanya lokasi wisata jika harga tanah semakin naik, dan masyarakat yang tidak memiliki modal yangbanyak tidak bisa memaksimalkan potensi pendapatan yang bertambah tapi justru kehilangan kesempatan untuk mendapatkan pertambahan penghasilan. Hasil ini sama dengan penelitian yang dilakukan oleh Suriya (2009) mengungkapkan bahwa "The richest quintiles of households would be the top gainer of the tourism benefit. Their income growth will range from around $3.50 \%$ to $4.0 \%$, The second richest households and the middle households were second and third largest gainers. However, the poorest and second poorest quintiles seemed not to gain anything of the benefit. They may even face the income drop a little bit"

\section{Dampak Non-Ekonomi \\ Kondisi Sosial Masyarakat Dampak Positif}

Masyarakat Desa Talun Kacang dan Desa Kandripada umumnya adalah masyarakat pedesaan, dimana nilai budaya dan sosialnya masih dijaga teguh sampai saat ini. Nilai - nilai sosial seperti toleransi dan gotong royong masih dijaga teguh oleh masyarakat, bahkan saat ini nilai-nilai tersebut cenderung berkembang menuju ke arah yang lebih baik. Menurut pernyataan dari Bapak Ismanto selaku pemilik persewaan speedboat di kawasan Waduk Jatibarang sebagai berikut:

"Kondisi sosialnya ya bagus, gotong royongya juga bagus. Nilai - nilai sosial dimasyarakat juga baik, kalau kita disini memang dari dulu dalam pengelolaan kawasan ini mengedepankan gotong - royongnya itu mas"

"Kalau sosial masyarakatnya masih sama, kalau gotong ronyongnya dari dulu sampai sekarang masih terjaga mas, malah cenderung lebih bagus mas. RW yang baru juga bagus, jadi kalau ada permasalahan masrakat juga dikumpulkan dan dicarikan solusinya. contohnya kalau disini ada yang jualan ikan bakar itu mas, kalau tempatnya 
penuh bisa duduk disini datau duduk dimana saja, ya gak apa - apa mas kita sama - sama dagang saling bantu membantu, nanti kan juga bisa beli minumya disini gorengan krupuk dan lain -lain juga ikut laku. Ini aja jalan menuju kesini juga swadaya dari masyarakat mas, ini buat ngluruk tanah ini juga habis ratusan juta, kita bersama - sama patungan"

Selain itu dengan adanya wisata ini berdampak pada peningkatan status sosial di masyarakat dimana masyarakat yang dulunya hanya bekerja sebagai petani tradisional ataupun buruh sekarang memperoleh sekarang memperoleh status baru sebagai pedagang atau bisa disebut wirausahawan, kesejahteraan masyarakat juga semakin membaik, adanya interaksi sosial masyarakat dengan wisatawan membuat pola pikir masyarakat semakin terbuka dan menambah wawasan masyarakat sekitar. Pendapat ini sama dengan yang dikemukakan Surwiyanata (2003) dimana pariwisata akan mengubah struktur sosial masyarakat dimana ada perpindahan pekerjaan masyarakat, pemerataan pendapatan masyarakat, berkurangnya perbedaan tingkat pendidikan dan kesempatan bekerja atau berusaha. Selain itu adanya modernisasi keluarga dimana anak dibebaskan untuk memilih apa yang dia mau dan peningkatan wawasan masyarakat, dimana ada perubahan ke arah yang lebih positif, terutama dalam hal berkomunikasi dengan sesama.

\section{Dampak Negatif}

Adanya interaksi masyarakat lokal dengan wisatawan secara otomatis akan berpengaruh terhadap kondisi sosial masyarakat, berdasarkan hasil pengamatan penulis, ada perubahan gaya bahasa yang ditunjukkan oleh beberapa pedagang yang berada di sana, mereka lebih nyaman menggunakan bahasa Indonesia dari pada bahasa Jawa terhadap wisatawan yang datang, perubahan sikap dan perilaku masyarakat juga sangat terasa, kebanyakan masyarakat di sana cenderung hanya berorientasi pada uang money oriented, sikap masyarakat ini tergambar ketika mereka hanya akan melayani wisatawan yang akan memberikan keuntungan untuk mereka, seperti pembeli. Ketika dilakukan penelitian ini penulis juga sempat kesulitan mencari informan karena ada beberapa pedagang yang tidak mau diwawancara, namun ketika barang dagangannya dibeli terlebih dahulu mereka mau untuk memberikan informasi yang dibutuhkan peneliti. Hal ini sama dengan penelitian sebelumnya Menurut de Kadt dalam Oktaviyanti (2013) efek demonstratif adalah perubahan nilai, sikap dan perilaku suatu masyarakat sebagai akibat dari kunjungan wisatawan ke daerah itu, terutama karena adanya interaksi dengan wisatawan dan usaha meniru budaya wisatawan. Dampak interaksi wisatawan dengan masyarakat lokal antara lain dapat dilihat dari perubahan gaya busana masyarakat yang meniru wisatawan, gaya bahasa, sikap dan perilaku yang ditunjukkan masyarakat lokal. Paul (2012) mengatakan bahwa "Globalization is accused of destroying the socio-cultural identity of the local communities and indigenous values, traditions and lifestyle"

Selain itu semakin ramainya kunjungan wisatawan ke Goa Kreo memunculkan adanya kemburuan sosial di masyarakat, menurut penuturan salah satu pedagang Goa Kreo, menuturkan bahwa :

"Tetap sama mas masih kaya dulu, tapi kadang ada warga masyarakat lain yang iri pengen juga dapat tempat buat jualan disini tapi kan gak semua orang bisa dapat tempat kan mas, soalnya disini juga tempatnya sempit"

Walaupun banyak masyarakat yang beralih pekerjaan namun tidak semua masyarakat memiliki kesempatan yang sama untuk memasarkan barang daganganya, masyarakat yang memiliki lokasi yang strategis untuk menjajakan barang daganganya cenderung akan memiliki pendapatan yang lebih besar, hal ini berdampak pada munculnya 
kecemburuan sosial diantara masyarakat karena adanya perbedaan pendapatan.

\section{Dampak Pariwisata terhadap Kebuda- yaan di Masyarakat Dampak Positif}

Objek wisata Goa Kreo dan Waduk Jatibarang dalam perjalanannya juga masih memegang nilai - nilai budaya yang ada, justru pengembangan budaya yang sudah menjadi warisan nenek moyang, masih terus dijaga dan dilestarikan sehingga dapat menjadi kearifan lokal yang berdampak pada kekhasan tempat wisata itu sendiri. Salah satu kebudayaan yang sampai sekarang ini masih sering dilakukan di kawasan wisata Goa Kreo adalah perayaan ritual kirap sesaji Rewanda. Kirap sesaji Rewanda bukan berarti kita menyembah pada roh kera (Rewanda) melainkan menyampaikan rasa syukur pada Allah SWT atas terciptanya alam yang indah, goa yang unik yang dilengkapi ratusan satwa kera yang berkeliaran bebas. Perayaan ini dilakukan setiap tahun dengan menyajikan hasil bumi yang disusun menjadi tumpengan, buahbuahan untuk makanan kera, dan replika kayu tiang Masjid Demak. Kemeriahan Perayaan ini melibatkan semua masyarakat sekitar baik yang tua ataupun muda, dan para wisatawan lokal maupun luar negeri.

Festival Sendratari legenda Gao Kreo merupakan salah satu festival terbaru. Festival ini baru satu kali dilaksanakan pada tahun 2015 ini, diharapakan festival Sendratari ini dapat dilaksanakan tiap tahun sehingga akan dapat menambah jumlah wisatawan yang datang ke Goa Kreo dan waduk jati barang. Kegiatan budaya ini tidak terlepas dari peranan Dinas Pariwisata Kota Semarang dalam upaya mempromosikan dan memajukan kawasan objek wisata Goa Kreo dan Waduk Jatibarang. Berdasarkan penuturan kepala Ka UPTD Goa Kreo Pak Asron sebagai berikut:

"Memang dari dinas pariwisata sendiri mentargetkan agar kunjungan wisata ke Goa Kreo semakin naik dari tahun ke tahun, salah satu upayanya ya dengan menumbuhkan budaya - budaya lokal yang ada, sehingga bisa menarik wisatawan untuk datang ke sini, salah satunya kemarin tahun 2015 baru saja dilakukan festival budaya Sendratari di sini, kemarin dalam rangka promosi juga ada festival durian yang diadakan disini mas"

Munculnya kesenian baru ini merupakan upaya pemerintah kota dan masyarakat sekitar dalam upaya menarik wisatawan untuk datang ke Goa Kreo, hal ini dilakukan untuk memenuhi kebutuhan wisatawan akan hiburan. Adanya ketertarikan wisatawan terhadap kebudayaan lokal ini akan menstimulus atau mendorong pada tumbuhnya kebudayaan kebudayaan baru atau melahirkan kembali kebudayaan lama yang semakin menghilang. Hal ini sama dengan pendapat Howe (Oktaviyanti, 2013) menyebutkan bahwa budaya pariwisata adalah budaya yang berdasarkan kebutuhan wisatawan. Interaksi wisatawan dengan masyarakat lokal memunculkan daftar kebutuhan dasar dan penunjang wisatawan dalam melakukan kegiatan pariwisata. Ini mengarah pada terciptanya pengadaan fasilitas tambahan yang harus disediakan oleh masyarakat lokal selaku tuan rumah destinasi wisata.

Dinas Pariwisata Kota Semarang memang memberikan respon yang positif terhadap kekayaan budaya lokal sehingga hal ini akan berdampak pada kepada tumbuh dan berkembangnya kebudayaan lokal yang ada, masyarakat sendiri menjadi termotivasi untuk menjaga dan mengembangkan kebudayaan lokal yang ada. Berdasarkan penuturan Bapak Widodo selaku Sekretaris Pengelola Waduk Jatibarang, beliau menuturkan sebagai berikut:

"Anak - anak disini juga senang berlatih tari - tarian mas, kebetulan klo latihan dilaksanakan di rumah saya, seneng kalau ikut pentas. Selain itu kan kalau kebudayaan seperti ini 
juga bisa di perlombakan atar sekolah, jadi manfaatnya positif'

Adanya regenerasi maka kebudayaan yang ada tidak akan hilang ditelan dengan jaman namun tetap akan menjadi kearifan lokal yang nantinya akan memberikan ciri kekhasan tersendiri buat daerah wisata Goa Kreo dan Waduk Jatibarang. Hal ini senada dengan yang diungkapkan oleh Irianto (2011) yang menyatakan bahwa pariwisata Sebagai sarana pengembangan budaya daerah, melalui atraksi budaya yang disuguhkan pada saat-saat tertentu, Kehidupan masyarakat dapat mendukung festival kesenian sebagai temporary events, Kesenian tradisional masyarakat desa dapat sebagai penunjang utama kegiatan temporary events sebagai festival kesenian masyarakat sekitar.

\section{Dampak Negatif}

Adanya interaksi dengan berbagai elemen masyarakat memungkinkan adanya akulturasi budaya dengan kebudayaan masyarakat luar, sehingga hal ini akan berdampak kepada melemahnya kebudayaan - kebudayaan local masyarakat Jawa, terutama masyarakat pedesaan yang menjaga tata-krama, nilai nilai seperti ini sekarang di rasa semakin lama semakin berkurang. Menurut penuturan Pak Ismanto, berikut:

"Kalau anak muda disini sudah beda dengan jaman dulu, sekarang anak anak disini sudah kayak anak - anak kota"

Walaupun hal ini tidak sepenuhnya merupakan dampak buruk karena ini menandakan kebudayaan lokal yang semakin moderen, namun hal ini memiliki dampak buruk bagi kehidupan lokal karena lama kelamaan masyarakat akan nyaman dengan kebudayaan tersebut dan meninggalkan kebudayaan lokal. Selain itu upacara adat seperti kirap sesaji yang merupakan acara yang penuh khikmat dan sakral saat ini seperti hanya menjadi upacara perayaan tahunan saja, karena disaksikan oleh banyak orang termasuk para wisatawan dan warga setempat.
Menurut penuturan salah satu pedagang di lokasi wisata tersebut menyatakan :

"Kalo ada kirap di sini rame mas, gak masalah gak ganggu upacaranya, mereka kan seneng karna di sana mungkin gak ada, kita juga seneng dagangan kita juga jadi laris. Dari dulu memang sudah ada kirap dan tiap tahun diadakan"

Sebagian besar masyarakat di kawasan Goa Kreo tidak mempermasalahkan kondisi tersebut, karena memang diadakannya acara tersebut selain mempertahankan kebudayaan yang ada adalah bertujuan untuk menarik wisatawan. Hal ini sama dengan yang disampaikan Oktaviyanti (2013) bahwa masih terdapat perdebatan apakah budaya pariwisata memberikan dampak positif atau negatif pada wisatawan dan masyarakat lokal. Pada akhirnya, tujuan adanya budaya pariwisata adalah untuk memenuhi kebutuhan wisatawan akan pengalaman budaya lokal. Meskipun terdapat perubahan pada sejumlah elemen budaya, termasuk di antaranya waktu pertunjukan ataupun fragmen yang disajikan, nilai dasar budaya lokal tetap harus dipertahankan.

\section{Dampak Pariwisata Terhadap Lingkungan Fisik}

Pembangunan infrastruktur seperti jalan dan fasilitas penunjang pariwisata di Goa Kreo dan Waduk Jatibarang saat ini memang sedang gencar dilakukan oleh Pemerintah Kota Semarang, saat penelitian ini dilakukan jalan menuju Goa Kreo juga sedang diperbaiki dengan menambahkan trotoar (bahu jalan) di sepanjang jalan masuk ke Goa Kreo. Selain perbaikan jalan lokasi pedagang yang ada di dalam kawasan wisata Goa Kreo juga sedang diperbaiki, kios-kios milik pedagang yang dulunya terbuat dari kayu akan direnovasi dan diganti dengan bangunan tembok permanen. Hal ini dituturkan oleh kepala Ka UPTD Goa Kreo yang mengatakan bahwa; 
"Sekarang pedagang-pedagang yang di atas sementara sedang digusur, bangunan yang dulu dari kayu akan diganti dengan bangunan permanen, selain itu juga akan ada fasilitas fasilitas lain yang dibangun disini untuk menunjang kebutuhan wisatawan. Kalau pedagang yang di bawah kiosya sudah permanen"

Adanya pembangunan yang ada di kawasan wisata tersebut tidak lain adalah upaya pemerintah kota untuk menaikkan tingkat kunjungan wisata di Goa Kreo.

Berbeda dengan lokasi wisata Goa Kreo jalan menuju Waduk Jatibarang malah belum diaspal, kondisi jalanya masih berupa jalan tanah. Selain itu fasilitas seperti kamar mandi, tempat parkir dan fasilitas pendukung lain juga belum memadai karena di sediakan seadanya oleh masyarakat sekitar. Menurut masyarakat di sana pembangunan jalan baru kan dilakukan pada tahun 2017

\section{PENUTUP}

\section{Kesimpulan}

Objek pariwisata Goa Kreo dan Waduk Jatibarang dapat memberikan manfaat yang positif dan negatif bagi masyarakat sekitar, manfaat tersebut mencakup di bidang ekonomi, sosial, maupun budaya. Berdasarkan penelitian yang telah dilakukan, maka dapat disimpulkan sebagai berikut:

1) Pengembangan objek wisata Goa Kreo dan Waduk Jatibarang telah mengubah tatanan didalam masyarakat, pengembangan objek wisata tersebut berdampak pada peralihan profesi masyarakat sekitar, akibatnya dari adanya peralihan profesi masyarakat tersebut pendapatan yang diterima masyarakat mengalaim kenaikan dibandingkan dengan sebelumya.

2) Di bidang ekonomi, adanya lokasi wisata membuka lapangan pekerjaan baru bagi masyarakat setempat, Masyarakat setempat dapat bekerja sebagai pedagang di Goa Kreo, menjadi pedagang di Waduk
Jatibarang, menyewakan speedboat, membuka rumah makan, berdagang souvenir dan yang lainya. Lokasi wisata tersebut juga membuat nilai ekonomis lahan pertanahan mengalami kenaikan harga.

3) Di bidang non - ekonomi seperti di bidang sosial, adanya lokasi wisata memungkinkan masyarakat sekitar untuk berinteraksi dengan wisatawan, dampak positifnya adalah kesejahteraan masyarakat menjadi lebih baik, wawasan masyarakat menjadi semakin luas, dan pola pikir masyarakat yang lebih terbuka, Selain itu nilai-nilai toleransi dan gotong royong juga semakin meningkat. Dampak negatifnya adalah adanya perubahan sikapdan gaya bahasa dan kecenderungan masyarakat yang berorientasi pada uang. Di bidang budaya, adanya lokasi wisata membuat budaya lokal yang ada semakin berkembang karena adanya apresiasi dari wisatawan yang datang dan pemerintah Kota Semarang, ritual budaya seperti rewanda juga masih dipertahankan sampai sekarang. Di bidang lingkungan, adanya lokasi pariwisata berdampak terhadap pembangunan infrastruktur yang ada seperti jalan da fasilitas penunjang pariwisata

\section{Saran}

Berdasarkan hasil pembahasan dan temuan penelitian di atas, maka saran yang dapat disampaikan adalah sebagai berikut:

1) Industri souvenir merupakan industri yang memiliki nilai ekonomis yang tinggi di kawasan wisata, di Goa Kreo dan Waduk Jatibarang belum ada penjual yang berjualan souvenir di kawasan wisata tersebut. Pemerintah Kota Semarang ataupun kelurahan setempat harus membantu dengan memberikan pelatihan kepada masyarakat tentang pembuatan industri kreatif. 
2) Saat ini Waduk Jatibarang sudah mulai ramai dikunjungi wisatawan, namun jalan menuju Waduk Jatibarang tersebut masih berupa jalan tanah, tempat parkir dan fasilitas pendukung di sana masih belum memadai, perlu adanya upaya dari pemerintah untuk segera meperbaiki kondisi jalan menuju Waduk Jatibarang dan penambahan fasilitas penunjang yang ada di sana.

\section{DAFTAR PUSTAKA}

Achadiat Dritasto, d. A. (2013). Analisis Dampak Ekonomi Wisata Bahari Terhadap Pendapatan Masyarakat di Pulau Tidung. Jurnal Online Institut Teknologi Nasional, 1-8.

Aditya, Y. (2015). Pengaruh Program Desa WIsata Terhadap Peningkatan Pendapatan Masyarakat (Studi Kasus Desa Bejiharjo, Kabupaten Gunung Kidul). Malang Universitas Brawijaya.

Ali, M. (2009). Pendidikan Untuk Pembangunan Nasional Menuju Bangsa Indonesia Yang Mandiri dan Berdaya Saing Tinggi. Jakarta: Imtima.

Amirullah, d. I. (2005). Pengantar Bisnis. Yogyakarta: Graha Ilmu.

Anstrand, M. (2006). Community-Based Tourism and Socio-Culture Aspects Relating to Tourism a Case Study of a Swedish Student Excursion to Babati (Tanzania). Jurnal. Sodertorn University Collage, School of Life Sciences.

Baltagi, B. H. (2005). Econometric Analysis of Panel Data. England: Jhon Wiley \& Sons, Ltd.

Baskoro BRA, d. C. (2008). Membangun Kota Pariwisata Berbasis Komunitas: Suatu Kajian Teoritis. Jurnal Kepariwisataan. 3(1).
Boone, L. E. (2007). Pengantar Bisnis Kontemporer. Jakarta: Salemba Empat.

bruijn, b. j. (asd). asd. asd, asd.

Donald R.Cooper, d. P. (2006). Bussines Reasearch Methods. New York: McGraw-Hill Companies, Inc.,.

Fadeli, C. d. (2003). Petunjuk Praktikum Kepariwisata Alam. Fakultas Kehutanan Universitas Gajah Mada Jurusan Konservasi Hutan Yogyakarta.

Ginting, Y. A. (2014). Perkembangan Objek Wisata Goa Kreo Terhadap Kehidupan Sosial Ekonomi Masyarakat. Jurnal Ilmiah Pendidikan Sejarah IKIP Veteran Semarang, 1-8.

Gitosudarmo, I. (2000). Manajemen Pamasaran. Yogyakarta: BPFE.

Hanif Alienda Wardhani, S. M. (45). sdf. $d f, 46$.

Hatton, M. (1999). Community Based Tourism in Asia-Pacific. Canada: School of Media Studies at Humber College.

Hausler, N. (2005). Definition of Community Based Tourism. Hanover: Tourism Forum Internasional at the Reisepavillion.

I Gede Pinanta, P. G. (2005). Sosiologi Pariwisata. Yogyakarta: Andi Offset.

I Wayan Suardana, d. N. (2015). Dampak Pariwisata Terhadap Mata Pencaharian Masyarakat Pesisir Karangasem: Pendekatan Pro Poor Tourism. PIRAMIDA 11(2), 76-87.

Irianto. (2011). Dampak Pariwisata Terhadap Kehidupan Sosial dan Ekonomi Masyarakat di Gili Trawangan Kecamatan Pemenang Kabupaten Lombok Utara. Jurnal Bisnis dan Kewisarusahaan. 7(3), 188 - 196. 
Iverson. (2001). Mamahami Keterampilan Pribadi. Bandung: CV. Pusataka.

Jarinto damanik, H. A. (2005). Penanggulangan Kemiskinan Melaluli Pariwisata. Yogyakarta: Kepel Press Yogyakarta.

Kasmir. (2006). Kewirausahaan. Jakarta: Rajawali Pres.

Kususmastuti, N. (2012). Pengaruh Pendapatan, Umur, Jumlah Tanggungan Keluarga pendapatan Suami dan Jarak tempuh Ketempat kerja Terhadap Curahan Jam Kerja Pedagang Sayur Wanita (skripsi). Semarang: Fakultas Ekonomika dan Bisnis Universitas Diponegoro.

Malyasana, D. (2011). Pendidikan Bermutu dan Berdaya Saing. Bandung: Remaja Rosdakarya.

Middleton, V. T. (2001). Resort : Management and Operation. John Wiley \& Sons, Inc.

Munandar, M. (2006). Pokok - Pokok Intermediate Yogyakarta: Gajah mada University Press.

Murphy, K. D. (2005). Psychological Testing, Principles and Applications Sisth Edition. New Jersey: Pearson Education International.

Nasikun. (2001). Bahan Kuliah; Isu dan Kebijakan Penanggulangan Kemiskinan. Yogyakarta: Universitas Gajah Mada.

Oka, A. Y. (2002). Perencanaan Starategis Pemasaran daerah Tujuan Wisata. Jakarta: Pradnya Paramita.

Oka, Y. A. (1982). Perencanaan dan Pembangunan Pariwisata. Jakarta: Pradnya Paramita.
Oktaviyanti, S. S. (2013). Dampak sosial Budaya Interaksi Wisatawan Dengan Masyarakat Lokal Di kawasan Sosrowijayan. Jurnal Nasional Pariwisata 5, 201-208.

Patin, D. d. (2005). Community Based Suitaineble Tourism. UK: UWISEDU.

Paul, B. D. (2012). The Impact of Tourism on Society. tidak diterbitkan.

Poniwatie, A. (2008). Analisis Faktor Faktor Yang Mempengarui Tingkat Pendapatan Pedaganag Pasar Tradisional Di Kota YOgyakarta. Jurnal NeO-Bis, 197-210.

Preechaya Chumsri, O. C. (2015). Guidelines on Developing Community Base Tourism to Suitanable Management of Tourist Attraction. Journal of Economics, Business adan Management, 3(6), 653-655.

Rini Sulistiawati, H. (56). as. asd, 65.

Riyanto, B. (2002). Dasar-dasar Pembelanjaan Perusahaan. Yogyakarta: BPFE.

S Pandit, N. (Ilmu Pariwisata Sebuah Pengantar Perdana). 1999. Jakarta: Prandya Paramita.

S, N. P. (1999). Ilmu Pariwisata Sebuah Pengantar Perdana. Jakarta : Pradnya Paramita.

Samuelon, P. A. (2008). Makro Ekonomi. Jakarta: Erlangga.

Sawir, A. (2001). Analisis Kinerja Keuanagan dan Perencanaan Keuangan Perusahaan. Jakarta: PT Gramedia Pustaka Utama.

Sedyawati, E. (2010). Budaya Indonesia (Kajian Akeologi, Seni, dan Sejarah. Jakarta: PT Raja Grafindo Persada. 
Soekadijo, R. (2000). Anatomi Wisata, Mamahami Pariwisata Sebagai Alternatif Linkage. Jakarta: Gramedia Pustaka Utama.

Sri Yuniarti, H. S. (54). asd. sd, 53.

Suansri, P. (2003). Community Based Tourism Handbook. Thailand: REST Project.

Sugiyono. (2013). Statistika Untuk Penelitian. Bandung: Alfabeta.

Sukirno, S. (2000). Ekonomi Pembangunan Proses, Masalah dan Dasar Kebijakan Pembangunan. Jakarta: UI-Press.

Sukirno, S. (2002). Teori Mikro Ekonomi. Jakarta: Rajawali Press.

Suparmoko. (1990). Pengantar Ekonomi Mikro. Yogyakarta: BPFE.

Suparmoko, d. M. (2000). Pokok - Pokok Ekonomika. Yogyakarta: BPFE.

Suriya, K. (2012). Impact of Communitybased Tourism in a Village Economy in Thailand: An Analysis with VCGE model. Tidak Diterbitkan.

Surwiyanata, A. (2003). Dampak Pembangunan Pariwisata Terhadap Kehidupan Sosial, Budaya, dan Ekonomi. Media Wisata Vol.2 No.1, 33-42.

Sutrisno. (2007). Manajemen Keuangan. Yogyakarta: Ekonesia.

Swantoro, G. (2004). Dasar - dasar Pariwisata. Yogyakarta: ANDI.

Syamsiah Ismail, Y. T. (2015). Dinamika Sosial Ekonomi Masyarakat (Studi peneleitian pada Masyarakat di Sekitar Tempat Wisata Pentadio Resort di Desa Pentadio Barat Kecamatan Telaga Biru Kabupaten Gorontalo). Jurnal Sosiologi, Fakultas Ilmu Sosial Universitas Gorontalo.
Timothy, D. (1999). Participatory Planing a View of Tourism in Indonesia. Annual Review of Tourism Research.

Tohar, M. (2000). Permodalan dan Pengkreditan Koperasi. Yogyakarta: Kanisius.

Umar, H. (2006). Metode Penelitian Untuk Skripsi dan Tesis Bisnis, Cetekan keenam. Jakarta: PT Gramedia Pustaka.

UNEP, d. W. (2005). MAking Tourism More Suitaneble: a Guide for Poicy Makers. Tidak diterbitkan.

Wahab, S. (2003). Managemen Kepariwisataan. Jakarta: PT Pradnya Paramita.

Yoeti, O. A. (1995). Pengantar Ilmu Pariwisata. Jakarta: Angkasa.

Yoeti, O. A. (1982). Perencanaan dan Pembangunan Pariwisata. Jakarta: Pradnya Paramita. 